Journal of Teacher Education for Sustainability, vol. 22, no. 1, pp. 124-139, 2020

\title{
Opportunity Inequality in Accessing Higher Education and Presentation of Equity Promotion Model to Achieve Sustainable Development: A Case Study of West Azerbaijan Province in Iran
}

\author{
Mohammad Hassani and Mahdi Najjari \\ Urmia University, Urmia, Iran
}

\begin{abstract}
This study was aimed to investigate the inequality of opportunity of access to the higher education centers and to present a model of reducing inequality of opportunities and to administer justice and fairness in order to achieve a sustainable development among the 17 cities and towns of West Azerbaijan Province, Iran. This research was a descriptiveanalytic and survey type of study in nature. The participants included 890 pre-university high school students who completed a set of questionnaires eliciting their perceptions on opportunity inequality in accessing higher education. Moreover, documents adopted from the responsible governmental bodies on this topic were analyzed. The collected data were analyzed using Pearson correlation coefficient, cluster analysis, path analysis and neural networks by means of Topsis, SPSS, and Excel softwares. The findings showed that there is inequality of opportunity of access to the higher education centers in cities of West Azerbaijan. Based on the path analysis, admission and individual-family indexes had the most and the least impacts on inequality of achieving higher education, respectively, among the cities of West Azerbaijan. Moreover, the neural networks model showed that the education indexes were the most important and the individual-family indexes were the least important ones in predicting the opportunity of accessing higher education in these cities. This study reveals that a three-componential model (namely, education, admission, and family-individual) along with their sub-components could be the basis for achieving education for sustainable development.
\end{abstract}

Key words: educational inequality, access to higher education centers, sustainable development

\section{Introduction}

Education for sustainable development is related to equip individuals, societies and governments for life and a continual understanding of the bioenvironmental aspects, social and economic sustainable development and acting according to it (Anyolo, Karkkainen, \& Keinonen, 2018). Education for sustainable development needs some learner- 
centered strategies and interactive teaching including critical thinking, participative decision-making and multi-method approaches (Ichinose, 2017). Sustainable education and education for sustainable development) have witnessed a deserved number of research studies in the recent years (Fedosejeva et al., 2018). There is no doubt that the system of education has a fundamental role in educating manpower and developing of society and efficient manpower will be fruitful when the opportunities are equal for all of them (Poorpaki, 2014).

Nowadays the educational inequality is one of the most important issues in the field of curriculum development. It has a determining role and a large share in promoting and improving the education and development (Shirkarami \& Bakhtiarpour, 2014). Access to the higher education means an opportunity to enter to the higher educational centers, though it is not a guarantee for higher education center admission (McGrath, 2014). By equal opportunity we mean preventing, omitting or reducing the discriminations among people regarding sex, race, physical conditions, age, language, social class etc. (Bennett, Both, \& Yeadle, 2001). According to Prodan (2015), access to higher education is a noticeable issue with direct consequences in educational policies, job market development and the quality of life. Where the educational inequality reaches to its excess limit the development rate will be lowered (Mousavi \& Hassani, 2011). The equality of opportunities includes a justice seeking view. It is regarded as an index in a developed society, a society in which people experience justice and fairness besides welfare and freedom. In this view, the equality of opportunities is considered a value. The education should improvise this value in personality system of developed human being (Shirkarami \& Bakhtiarpour, 2014).

Providing equal conditions for having access to the equal educational opportunities is important from different political, social and economic aspects (Opheim, 2004). Hannum (2000) believes that facilitating the access to the education and decreasing the costs for the poor families can lead to reducing of inequality related to poverty and sex. Mayers (2003) on educational opportunities states that the educational equality has not been realized yet since it put forth 120 years ago. Also, according to Vergolini (2016), an increase in participation in higher education centers reduces the inequality of educational opportunities and leads to the equality and justice. The higher education centers entrance for the people who had some obstacles to enter should be facilitated because these people may have skills and experiences that are valuable for national and social development of the nation. Access to the equal education is one of the basic human rights (Qian \& Smyth, 2008). Children do not enjoy equal conditions due to belonging to the different economic, social and cultural class and the degree of family education which creates opportunities for them because they do not enjoy the same status. The concept of inequality is formed in their minds from the starting point of the education when the observe that they enjoy t different educational facilities and this issue is revealed more (Sabbagh, Resh, Mor, \& Vanhuysse, 2005). The educational equality is realized when all people are equal to have access to the same education. This is an accepted goal in international level but is has not been fully realized yet (Leinonen, 2000).

Based on what was discussed above, the importance of equality of access to the education was clearly explained. Since the educational inequality is observed more in deprived areas and because West Azerbaijan is one of the deprived areas of the country thus considering the issue of educational inequality seems very important. Therefore, 
ignoring this issue will have negative consequences socially, economically, politically and culturally for the West Azerbaijan in future. The aim of this research was to analyze the inequality of access to the higher education centers and to present a model of reducing inequality of opportunities and administering justice to achieve a sustainable development among the cities of West Azerbaijan.

\section{Theoretical Basis of the Research}

Sustainable development means integrating economic, social and bioenvironmental goals to maximize the welfare of the human being without damaging the capabilities of the future generation for meeting their needs (the Cooperation and Economic Development Organization 2001). We can define the sustainable development as increasing the capacities and mobilizing the national system in all dimension and in its political, social, economic, cultural and bioenvironmental subsets to the extent that the national system be able to answer all increasing needs and to be adaptable with the environment and to have interaction with various internal and external conditions. Sustainable development is believed to consist of three dimensions: the protection of the natural environment, the maintenance of economic vitality, and the observance of specific social considerations (Veissona \& Kabaday, 2018; Pipere, Veisson, \& Salìte, 2015; Heasly, Lindner, Iliško, \& Salite, 2020). Education for Sustainable Development (ESD) has been viewed as education that helps people develop the attitude, skills, and knowledge to make well-informed decisions for the benefit of the present and future generations (Anyolo, Karkkainen, \& Keinonen, 2018). By relating the main functions of higher education to research, teaching and everyday sustainable activities clearly, the general approach of the higher education for sustainable development, the vague concept of sustainable development in real world is proved to the students. A systematic approach defines that in a university, as a small city, if the goal is the sustainable development, all sections related together, should be considered to this goal. This integrated and supplementary approach is an ideal goal for most higher education institutes. This approach provides a framework for implementing the sustainable development within the organization. It is seeking to remove the existing obstacles among the performing units of the institutes (Faham \& Rezvanfar, 2015).

The theory of educational equality has its origin in opinions of Rawls (1971). According to Rawls the three principles of equality of opportunities in the field of educational systems are: 1) providing educational facilities for qualified people 2) providing minimum education for every individual 3) creating facilities and special provisions for each deprived group. Based on this, Rawles and Farel $(1994,1999)$ state three forms of educational system equality: the equality of access, input equality and output equality. Also, Farel and other scholars mentioned that equality of education has different dimensions which include: race, ethnical group, sex, economic and social status, geographical location etc. (Chenge, 2009). Educational equality and justice based on the theories of social equality and social encompassing includes the following aspects: equality of access, equality of conditions, the equality of participation and the results (Samons, 2010). The contemporary theories of social system and stratification fall into two competitive approaches: the contrast theory approach and the structural-functional approach. The main difference of these two paradigms is on the role of education in modern societies and the fundamental reasons of educational inequalities. Although the structuralism- 
functionalism accepts that there is inequality in education they argue that the existence of inequality of education is mainly due to differences in aptitude, attitude and responsibility among every single student rather than existing deficiencies consequences along the system. On the contrary, the theorists of contrast Marxist oriented scholars argue that social and educational inequality is the result of main deficiency in social system. These theorists view the education as an "ideological governmental tool" which is solely at the service of the ruling class (Chenge, 2009).

\section{The Review of Literature}

Darban Astaneh et al. (2016) found that the border cities suffer an educational inequality regarding distribution of facilities and enjoying the good education compared to the cities in center of the province. This inequality is more noticeable in southern part of the country. Shir Karami and Bakhtiarpour (2015) found that there is an inequality among different areas and genders regarding access to the educational opportunities. Samery et al. (2014) in their study showed that there is educational inequality among the male and female students and also in different educational districts. According to Rees et al. (2015) there is a fundamental difference between the local governments and the students' chance of being present in higher education center regarding the individual features (academic achievements and strong background) and features related to the school they attend. Agrawal (2014) studied the inequalities of educational opportunities in India during 1983-2004. The results showed inequalities of educational opportunities during the years of the study. Necate et al. (2014) in a research showed that there were inequalities in educational opportunities in Turkey. The findings of Akpoyovwaire Samuel (2013) showed that there is gender inequality in access to education in Nigeria. Bar Haim and Shavit (2013) founds that there was inequality in access to the education in 24 countries in Europe. Yaaboski, Nolan stated in his research that system of Education in Kenya is an example that shows the impact of school system in access to higher education.

Reviewing the literature and studying the effective factors on access to the higher education centers, the conceptual research model in Figure 1 has been presented. In this line the following research questions was proposed and studied:

1. Are there any inequalities in the opportunities of access to higher education centers among the cities of West Azerbaijan?

2. What are the privileged, half-privileged and deprived cities regarding the opportunities of access to the higher education centers?

3. What is the optimal model of reducing the inequality of opportunity of access to the higher education centers? 


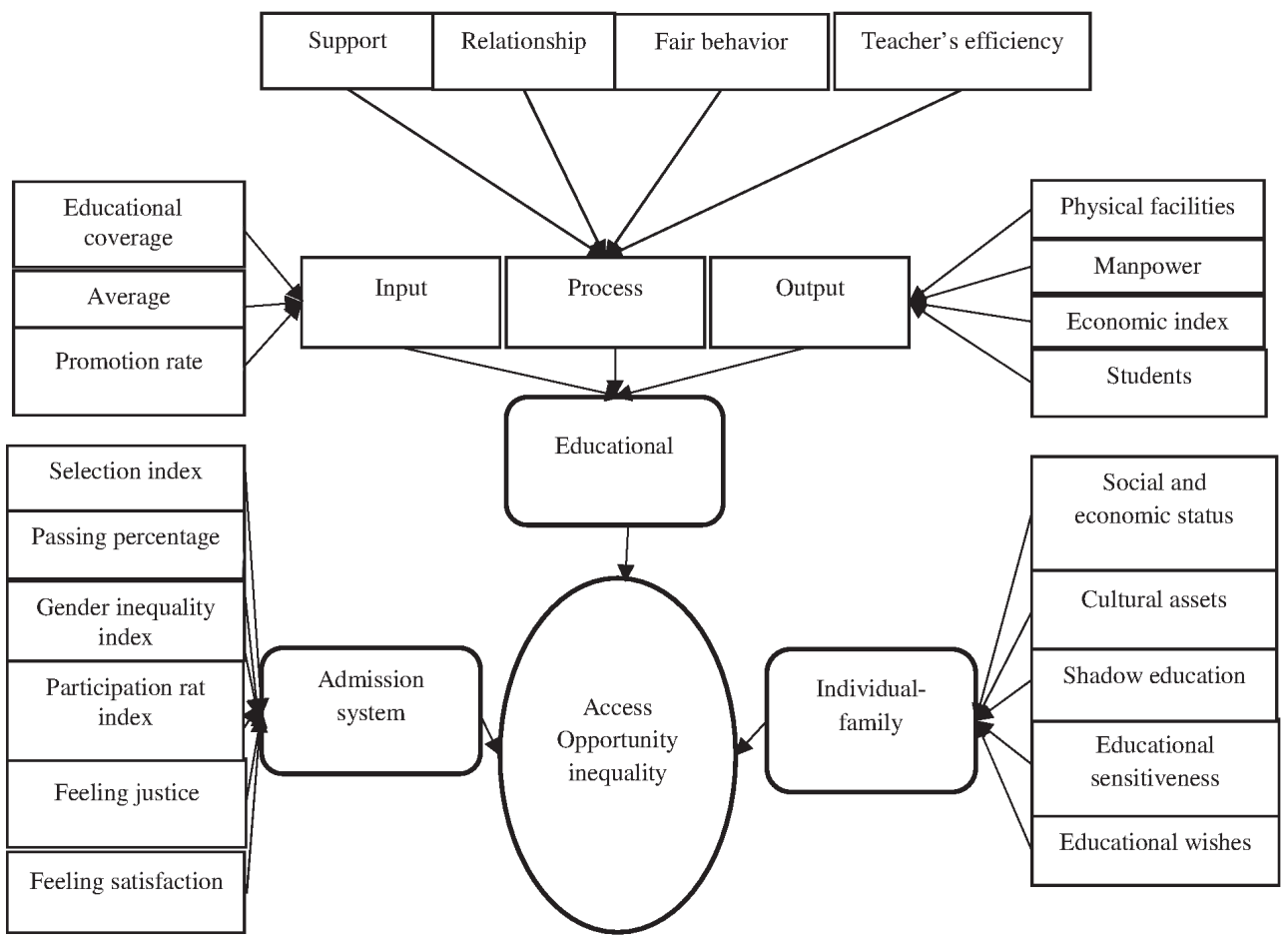

Figure 1. Conceptual model of research

\section{Methodology}

Regarding the objectives this research is an applied one. Considering the method of data collecting, it is a descriptive-analysis one. It was done through documentation and using questionnaires. The statistical population was the students studying in preuniversity grade in all cities of West Azerbaijan. The sampling was done through Cochran formula which 892 students were selected through relative stratified sampling. To collect the data, the researchers used two methods i.e. referring to the documents and using questionnaire. In documentation section, the statistical information related to nationwide university entrance exam in 2016 of whole province, the statistical information of education office of province, census and demographic information in 2016, census year book of 2014, informatics data of census center of Iran and questionnaires were used. The face validity of the questionnaires was confirmed by some professors of educational science faculty and the construct validity of them was confirmed through factorial analysis. This analysis was done through exploratory data analysis by main components analysis by Varimax rotation. The value of Kaiser-Mayer-Olkin equaled 0.798 and the chisquare of Bartlett Sprite Test was 2992.57 which was in 0.01 level of significance. It indicates the $\mathrm{KMO}$ and variables of the sample for doing factorial analysis. The criteria for omitting or confirming the items was having a factor load more than 0.4 and therefore the items having factor load smaller than 0.4 were discarded at the final analysis. To determine the reliability of questionnaires, the researchers used Cronbach's Alpha which the total coefficient of the questionnaire was estimated to be 0.75 , it indicated a suitable 
reliability of the tool. To do the calculations SPSS software was used. Using Topsis model and item weighting of Entropy, the ranking of the cities in province was done in each index. It worth to mention that Topsis model as a multiple attribute decision making model is a simple but efficient method in priority processing.

To measure the inequality of the cities in each index, the researchers used the coefficient of variation. Then, through regression analysis the analysis of effective factors on inequality of opportunities of access to the higher education was done. Using the advanced statistical techniques of path analysis model and the artificial neural networks, the researchers presented a model of predicting effective factors on inequality of access opportunity in cities of province. The path analysis model is used as a technique for illustrating a relationship system between the variables. In this way that the correlation coefficient of every independent variable having a dependent variable is divided into its direct effect of that independent variable on the dependent variable and its indirect effects through model making among variables (Mousavi \& Hassani, 2011). One of the methods of model making among variables is artificial neural networks. This method does not impose any early assumptions for distributing the data. In this network the information is processed implicitly, based on this if some part of the cells of the network are omitted or have a malfunction, we can still reach a correct answer. In this study to present a model of forecasting the researchers used the artificial neural network. By reviewing and summarizing the researches done related to the indexes of inequalities, four indexes were designed to study the inequality of access opportunity to higher education centers in comparative form among the cities (see Table 1).

Table 1

The System of Indexes Used in the Study

\begin{tabular}{|c|c|}
\hline $\begin{array}{l}\text { Inequality sources of } \\
\text { access opportunities }\end{array}$ & Indexes \\
\hline Individual and family & $\begin{array}{l}\text { 1. social-economic status } 2 \text {. The average of cultural asset score } 3 \text {. The } \\
\text { average of educational wishes score of parents } 4 \text {. The average score of } \\
\text { educational sensitivity of parents } 5 \text {. the average score of shadow education }\end{array}$ \\
\hline Educational & $\begin{array}{l}\text { 1. The ratio of the class to the students at secondary high school level } \\
\text { in district } 2 \text {. The number of high schools for each } 100 \text { students at high } \\
\text { school level in district } 3 \text {. The number of prayer halls for each } 1000 \text { stu- } \\
\text { dents in district } 4 \text {. The number of sport hall for each student in district } \\
5 \text {. The number of the libraries for each } 1000 \text { student in district } 6 \text {. The } \\
\text { capitation grants of educational space for each student } 7 \text {. The ratio of } \\
\text { female students to the male students at high school level in district } 8 \text {. The } \\
\text { ratio of book to the students at the high school level in district } 9 \text {. The } \\
\text { ratio of the girl students to the total number of the students at the high } \\
\text { school level } 10 \text {. The ratio of the male students to the total number of } \\
\text { the students at high school level, the ratio of teacher to the student at } \\
\text { the high school level } 11 \text {. The ratio of teachers holding a master and } \\
\text { PhD degree at the high school level for each } 100 \text { students at the high } \\
\text { school level in district } 12 \text {. The ratio of female teachers to the female } \\
\text { students at high school level in district } 13 \text {. The ratio of the staff to the } \\
\text { student for each } 100 \text { students at high school level in district } 14 \text {. The } \\
\text { ratio of female head teachers to the number of total head teachers } \\
15 \text {. The ratio of female head teachers holding a master degree and PhD }\end{array}$ \\
\hline
\end{tabular}


Continuation of Table 1

to the total number of the head teachers 16 . The ratio of the head teachers to the head teachers of the district 17 . The ratio of development credits to the number of the students at high school level in district 18. The ratio of the cost of student per captia to the number of the students at the high school level in district 19 . The ratio of the average of feeling with the justice and fairness 20 . The average of the understanding of support 21. The average of relationship with the school staff 22 . The average of teacher efficiency 23 . The average score of the students at the final level at high school in each district 24. The coefficient of academic coverage at high school level in each district 25 . the rate of grade promotion at the final level of high school

Admission system 1. The selection index 2. Gender inequality index 3. Admission to university percentage 4 . The rate of participation 5 . The average score of the feeling of justice and fairness of the candidates 6 . the average score of feeling satisfaction of the candidates

\section{Results}

\section{Inequality of Access Opportunity to Higher Education among the Cities of West Azerbaijan}

In this section the cities of West Azerbaijan have been ranked according to enjoying the indexes of the research using the Topsis model. Among the 17 cities in West Azerbaijan in individual and family index Orumieh ranked first and Sardasht came last. In education index, Miandooab ranked first and Shoot came last. In this research the integrated indexes the whole status showed an inequality of access opportunity to the higher education which Orumieh and Chalderan were the most privileged and least privileged cities respectively regarding the integrated indexes of access opportunities to higher education. Using the variation coefficient model it was revealed that the most inequality degree that is 0.85 was in integrated index and the least belonged to the individual background and family index that is 0.52 (Table 2).

Table 2

Ranking of Cities of West Azerbaijan Regarding the Indices of the Research

\begin{tabular}{lcccccccc}
\hline \multirow{2}{*}{$\begin{array}{c}\text { The name of } \\
\text { the city }\end{array}$} & \multicolumn{2}{c}{$\begin{array}{c}\text { Individual-family } \\
\text { indexes }\end{array}$} & \multicolumn{2}{c}{$\begin{array}{c}\text { Educational } \\
\text { indexes }\end{array}$} & \multicolumn{2}{c}{$\begin{array}{c}\text { Accepting system } \\
\text { indexes }\end{array}$} & \multicolumn{2}{c}{$\begin{array}{c}\text { Integrated } \\
\text { indexes }\end{array}$} \\
\cline { 2 - 11 } & Topsis & Rank & Topsis & Rank & Topsis & Rank & Topsis & Rank \\
\hline Ouromeih & 0.8784 & 1 & 0.5407 & 3 & 0.8534 & 2 & 0.8482 & 1 \\
\hline Oshnavieh & 0.4841 & 3 & 0.0562 & 15 & 0.1557 & 15 & 0.0832 & 13 \\
\hline Bokan & 0.3029 & 8 & 0.2506 & 5 & 0.9452 & 1 & 0.6063 & 3 \\
\hline Poldasht & 0.2243 & 15 & 0.0630 & 14 & 0.0522 & 16 & 0.0441 & 16 \\
\hline Piranshahr & 0.2487 & 14 & 0.0813 & 11 & 0.2092 & 13 & 0.0841 & 12 \\
\hline Tekab & 0.2756 & 10 & 0.0724 & 12 & 0.3360 & 10 & 0.1089 & 11 \\
\hline Chaldoran & 0.1868 & 16 & 0.0328 & 16 & 0.0333 & 17 & 0.0129 & 17 \\
\hline Chaipareh & 0.2819 & 9 & 0.1085 & 9 & 0.4226 & 8 & 0.1502 & 8 \\
\hline Khoi & 0.5832 & 2 & 0.3162 & 4 & 0.8084 & 3 & 0.8274 & 2 \\
\hline
\end{tabular}


Continuation of Table 2

\begin{tabular}{lcccccccc}
\hline Sardasht & 01364 & 17 & 0.0684 & 13 & 0.2305 & 12 & 0.0768 & 14 \\
\hline Salmas & 0.4415 & 4 & 0.1831 & 6 & 0.4509 & 7 & 0.2181 & 6 \\
\hline Shahindezh & 0.2509 & 13 & 0.0964 & 10 & 0.3257 & 11 & 0.1198 & 10 \\
\hline Shoot & 0.2572 & 12 & 0.0250 & 17 & 0.1725 & 14 & 0.0490 & 15 \\
\hline Makoo & 03185 & 6 & 01186 & 8 & 0.3497 & 9 & 0.1433 & 9 \\
\hline Mahabad & 03400 & 5 & 0.8595 & 2 & 0.5244 & 5 & 0.3496 & 5 \\
\hline Meindooab & 0.3134 & 7 & 09196 & 1 & 0.5452 & 4 & 0.3888 & 4 \\
\hline Naghadeh & 0.2602 & 11 & 0.1528 & 7 & 04607 & 6 & 0.1889 & 7 \\
\hline Variation coefficient & 0.52 & 0.71 & 0.62 & 0.85 & & & & \\
\hline
\end{tabular}

\section{Privileged, Half Privileged and Deprived Cities Regarding the Access Opportunity to the Higher Education Centers}

The results of the cluster analysis showed that considering the access opportunity to the higher education centers (the integrated section indexes) Ouromeih and Khoi were privileged ones, Salmas, Bokan, Mahabad and Miandooab half privileged ones and Mako, Tekab, Naghadeh, Chaiparh, Shahindezh, Shoot, Oshnavieh, Piranshahr, Chaldoran, Poldasht and Sardasht were among the deprived cities.

Table 3

Ranking of the Cities Considering Privileges in Integrated Index

\begin{tabular}{|c|c|c|c|}
\hline Index title & Deprived cities & Half privileged cities & Privileged cities \\
\hline Integrated & $\begin{array}{l}\text { Mako, Tekab, Naghadeh, } \\
\text { Chaipareh, Shahidezh, Shoot, } \\
\text { Oshnavieh, Chaldoran, } \\
\text { Poldasht, Sardasht Piranshahr }\end{array}$ & $\begin{array}{l}\text { Salmas, Bokan, } \\
\text { Mahabad, Miandooab }\end{array}$ & Ouromeih, Khoi \\
\hline
\end{tabular}

\section{Optimal Model of Reducing the Inequalities of Access Opportunities to the Higher Education Centers}

In this section the indexes used in this research are as independent variables and integrated section which are indicator of inequality as dependent variable to specify the effects of each of the different indexes in inequality of access opportunity. To study the effects of the simultaneous of independent variables on the degree of inequality of access opportunity the researchers used the multiple regression model simultaneously. The coefficient regression and $\mathrm{F}$ statistics and the goodness of fit models are given in Table 4. The multiple correlation coefficient and the effective indexes suggest that the effect of all indexes of research were significant level of 96 percent (Table 5). The indexes entered in the model explain the variation of inequalities of access opportunities to the higher education centers in West Azerbaijan cities.

Reviewing the $\beta$ values in Table 6 , it is revealed that a unit of variation in standard of deviation of individual and family background, education, accepting system will create as much as $0.32,0.56,0.68$ unit of variation in inequality of access opportunities to higher education centers respectively in cities of west Azerbaijan province. 
Table 4

Multiple Regression Analysis of Inequality of Access to the Higher Education Centers

\begin{tabular}{cccc}
\hline $\begin{array}{c}\text { Multiple correlation } \\
\text { coefficient }\end{array}$ & $\begin{array}{c}\text { Coefficient } \\
\text { determination }\end{array}$ & $\begin{array}{c}\text { Corrected coefficient } \\
\text { of determination }\end{array}$ & $\begin{array}{c}\text { Error of } \\
\text { the criteria }\end{array}$ \\
\hline 0.96 & 0.92 & 0.90 & 0.081 \\
\hline
\end{tabular}

Table 5

The Analysis of Multiple Variations of Inequalities of Access Opportunities to Higher Education Center

\begin{tabular}{lcccccc}
\hline The source of variation & $\begin{array}{c}\text { Sum of } \\
\text { the squares }\end{array}$ & $\begin{array}{c}\text { Degree of } \\
\text { freedom }\end{array}$ & $\begin{array}{c}\text { The mean } \\
\text { square }\end{array}$ & F statistics & P-value \\
\hline The regression effect & 1.04 & 3 & .349 & \multirow{2}{*}{52.18} & 0.001 \\
\hline Remainder & 0.8 & 13 & 0.007 & & & \\
\hline Total & 1.13 & 16 & - & & \\
\hline
\end{tabular}

Table 6

Statistics of Regression Model Coefficient Related to Different Sections of Inequality of Opportunity of Access to Higher Education Centers

\begin{tabular}{lccccc}
\hline \multirow{2}{*}{ Variable } & \multicolumn{2}{c}{ Unstandardized coefficient } & $\begin{array}{c}\text { Standard } \\
\text { coefficient }\end{array}$ & \multirow{2}{*}{$\mathrm{T}$} & P-value \\
\cline { 2 - 4 } & $\mathrm{B}$ & B error & $\mathrm{B}$ & & \\
\hline Y-intercept & -0.20 & 0.04 & - & -4.55 & 0.001 \\
\hline Individual-family & 0.49 & 0.18 & 0.32 & 3.38 & 0.001 \\
\hline Educational & 0.57 & 0.14 & 0.56 & 5.41 & 0.001 \\
\hline Admission system & 0.67 & 0.10 & 0.68 & 6.32 & 0.001 \\
\hline
\end{tabular}

Dependent variable: Compilation indices (inequality of access to higher education).

\section{A Path Analysis Model of Equality of Opportunities of Access to the Higher Education Centers}

In this section applying multi variation regression statistical technique and path analysis the researchers tried to study the effecting paths (direct and indirect) of independent variables on dependent variable. Considering that the determining the real effect of each independent variable multi-colinearity should be low, the researchers used the VIF, the multi-colinearity method to determine the existence or nonexistence of relationship (Mohammadi, 2003; cited in Sammeri et al., 2015). If the value of VIF is smaller than 10, it indicates lack of a multi-colinearity between the independent variables. The results in Table 7 suggested a lack of multi-colinearity between independent variables, therefore the direct effects for each variable is reliable. 


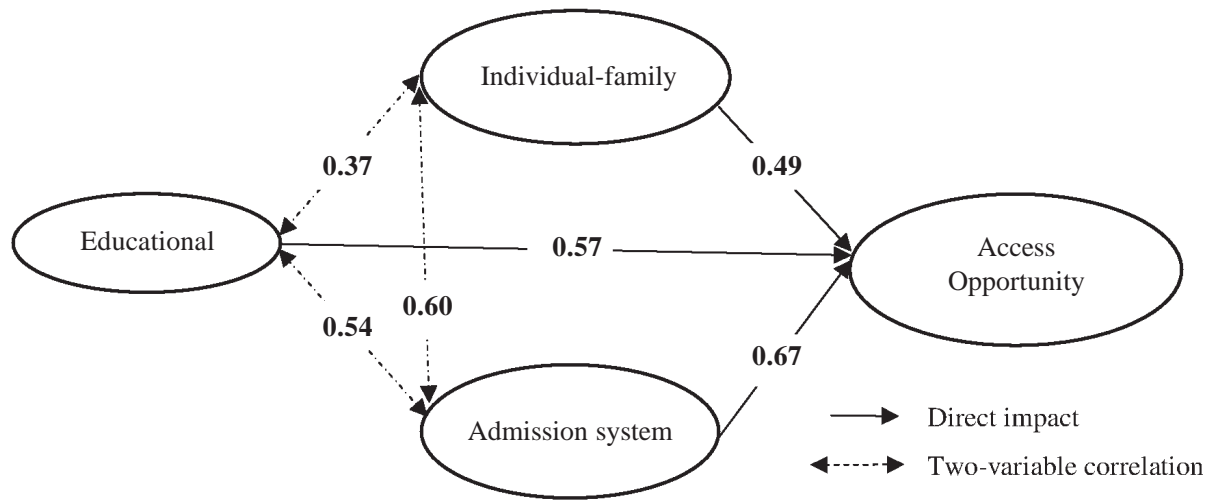

Diagram 1. The diagram of path analysis of effective factors on access opportunities to the higher education centers

Source: the researchers' calculations in 2018

Regarding the resulted model of path analysis, we can calculate the degree of equality of access opportunities. The direct and indirect and general effect of the independent variables on the equality of access opportunities are as follows.

Table 7

The Direct, Indirect and Total Effects of Independent Variables on the Equality of Access to Higher Education

\begin{tabular}{lcccc}
\hline Independent variables & Direct effects & Indirect effects & Total effect & VIF \\
\hline Individual-family & 0.49 & 0.19 & 0.68 & 3.02 \\
\hline Educational & 0.57 & 0.27 & 0.84 & 3.52 \\
\hline Admission system & 0.67 & 0.25 & 0.92 & 4.18 \\
\hline
\end{tabular}

Source: the researchers' calculations in 2018

According to Table 7 , the accepting system variables with a degree of 0.92 had the most and the individual and family variables with a degree of 0.68 the least effects on the equality of access opportunities to the higher educational centers of West Azerbaijan province.

\section{Predictive Model of Equality of Access Opportunities to Higher Education Centers}

To have a precise prediction of access opportunities to the higher education centers in West Azerbaijan, the researchers used a neural network based on the independent variable. From the total data used in neural network about 64.7 percent of data entered the model for education and 35.3 percent for the experiment. In the model which was used, Sigmoid function used for output of the data and hyperbolic tan function used for hidden layers. For more precision in model, the data were normalized. Figure 2 shows the graphical relation of input and output of data. In this figure, the relationship of input and output of data had been through two hidden layers which the first layer had two neurons and the hidden layer of the second one had two neurons. 


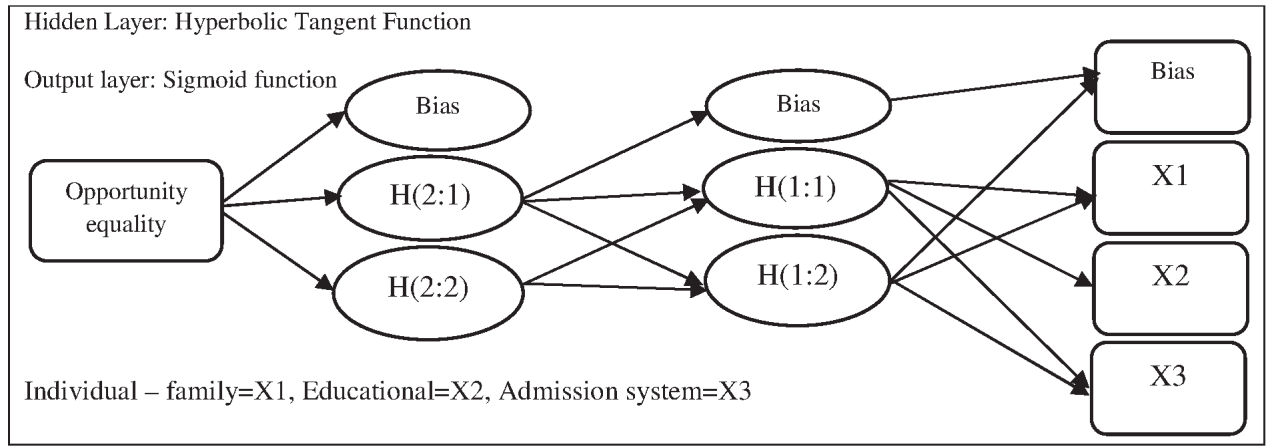

Figure 2. The graphical relationship of input and output of data and their relationship through their hidden layers

Source: the researchers' calculations in 2018

The precision evaluation of the neural network suggests an average correlation of 0.97 the determination coefficient of 0.96 and mean square error for education stage was 0.01 and for the experimental one 0.003 which indicates precision and reliability of the model in forecasting the equality of opportunity of access to the higher education centers. Table 8 shows the importance of independent variables in forecasting the equality of opportunity of access to the higher education among the cities of west Azarbijan province. In this table the most impact was on education section indexes and the least impact was on individual and family background in predicting.

Table 8

Importance of Independent Variables

\begin{tabular}{ccc}
\hline Variables & Importance & Normalized importance \\
\hline Individual-family & 0.105 & 22.3 \\
\hline Educational & 0.470 & 100.0 \\
\hline Admission system & 0.425 & 90.4 \\
\hline
\end{tabular}

Source: the researchers' calculations in 2018

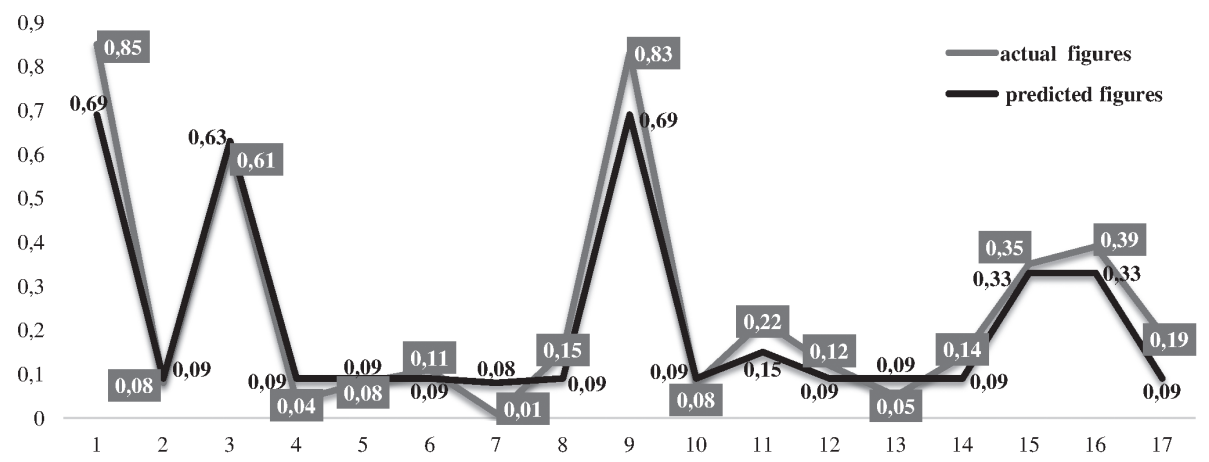

Figure 3. The actual and predicted figures for equality of access to higher education opportunities

Source: the researchers' calculations in 2018 
Figure 3 shows the values for access opportunities to higher education centers with the forecasting values of neural networks. The diagram indicates an acceptable precision of the model in forecasting of equal access opportunities.

\section{Discussion and Conclusion}

In this research the inequality of access opportunity to higher education centers in cities of West Azarbijan was studied in four catgories of indexes. The results of rankings of the cities showed that among 17 cities in individual and family index, Ouromieh ranked first and Sardasht ranked the last. In education index, Miandooab ranked first and Shoot ranked the last city. In accepting system index Bookan ranked first and Chaldooran ranked last. In this study the integrated indexes showed the total condition of inequality of access opportunities. The study of ranking of cities of West Azerbaijan in integrated indexes revealed that Ouromieh and Chadooran were as the most privileged and the least privileged cities respectively regarding the access opportunities to higher education centers. Using the variation coefficient model it was revealed that the highest degree of inequality i.e. 0.85 was in integrated index and the lowest degree of inequality i.e. 0.52 was in individual and family background index. The results of ranking among the cities of West Azerbaijan regarding the privilege of opportunity of access to higher education centers (the indexes in integrated section) showed that Salmas, Bookan, Mahabad and miandooab were half privileged and Makoo, Tekab, Naghadeh, Chaipareh, Shahindezh, Shoot, Oshnavieh, Piranshahr, Chalderan, Poldasht and Sardasht were deprived cities. According to the results of path analysis index of accepting system was the most effective one and the individual and family background had the least direct effect on the equality of access opportunities to the higher education centers. The forecasting results employing the neural networks also showed that education index had the highest effect and the individual and family background index the lowest effect in forecasting the equality of access opportunities to the higher education centers.

Inequality in all levels and forms especially district inequality can have dire unpleasant macro and micro consequences. The higher education is the foundation stone of every society. The issues like equality, justice, freedom and equal opportunities, the individuals' rights and so on are realized just through the correct educational planning. Wherever the inequality degree of education is too high the rate of the development will reduce. Entrance to the higher education centers for individuals and districts that face with hindrances should be facilitated because these people may have skills and experiences that are valuable for the nation's development. Also these inequalities have a deep negative effect on individual's job achievement and development of the district. Thus, if a society wants to move in the growth and development direction, it has to reduce the inequalities of education access opportunities. The equality of education can make a radical change in all fields and prepare the ground for people to show their talents and aptitudes in a macro level. Providing equal conditions for having access to the education is politically, socially, economically and culturally very important. The researchers suggest the facilitation of access to higher education centers for individuals according to the findings of their research in order to reduce the inequalities. The realization of the goals of millennium development and achieving the vast sustainable and fair development needs lifting the discriminations and racial, sexual, ethnical inequalities. Therefore, the 
factors that are effective in access to higher education centers and cause inequality in access to the higher education are: individual and family factors, education and admission system. Therefore, all these factors should be considered in order to reduce the inequalities. It should be tried to lower these inequalities to the lowest level because from the educational justice every single individual by creation have some rights which the Islamic system of education should prepare the ground for the growth and flourishing of their innate spiritual talents. The equality of opportunities is generally accepted principle and is discussed as an ideal view in political negotiations. This necessary issue as a reform movement is always considered by scholars and education authorities in different countries. Therefore, in order to achieve a sustainable development, one of the important factors that should be considered by education authorities is the equality of education.

\section{References}

Agrawal T. (2014). Educational inequality in rural and urban India. International Journal of Educational Development, 34(1), 11-19.

Akbari, T (2016). Ranking of Deprivation of Education Areas of Ardebil Province for Modeling of Optimal Allocation of Credit. Unpublished Doctoral Dissertation for Educational Management, Urmia University.

Anyolo, E. O. Karkkainen, S., Keinonen, T. (2018). Implementing Education for Sustainable Development in Namibia: School Teachers' Perceptions and Teaching Practices. Journal of Teacher Education for Sustainability, 20(1), 64-81.

Bar Haim, E. Shavit. Y. (2013). Expansion and inequality of educational opportunity: A comparative study. Research in Social Stratification and Mobility, 31, 22-31.

Bennett, C., Both, C., \& Yeadle, S. (2001). Mainstreaming equality in the committees of the Scottish parliament. University of strathclyde, 5(7), 10-21.

Cheng, H. (2009). Inequality in basic education in China: A comprehensive review. International Journal of Educational Policies, 3(2), 81-106.

Choi, Y., \& Park, H. (2016). Shadow education and educational inequality in South Korea: Examining effect heterogeneity of shadow education on middle school seniors' achievement test scores. Research in Social Stratification and Mobility, 44(1), 22-32.

Darban Astaneh, A., Tahmasebi, S., Rezaei, P. (2016). Analysis Pattern of Inequality in Educational Spaces of Iranian Cities. Quarterly Journal of Educational Planning, 9(1), 50-31.

Faham, E., Rezvanfar, A. (2015). Training for Sustainable Development in Higher Education. Sharif Industrial University, First Edition. Tehran, Iran.

Fedosejeva, J., Boče, A., Romanova, M., Ilisko, D., \& Ivanova, O. (2018). Education for sustainable development: The choice of pedagogical approaches and methods for the implementation of pedagogical tasks in the anthropocene age. Journal of Teacher Education for Sustainability, 20(1), 157-179.

Gholami Pirzad, A., Gholami Pirzad, E., Palizban, F., \& Ghazanfari, Z. (2015). Sexual justice with injustice in educational system of Ilam province. Journal of Developmental Strategies for Medical Education, 2(2), 44-35.

Hannum, E. (2000). Educational, expansion and demographic. Harvard: Institute for International Development. 
Heasly, B., Lindner, J., Iliško, Dz., \& Salīte, I. (2020). From initiatives, to insights, to implementation of the sustainability and securitability agenda for 2030. Discourse and Communication for Sustainable Education, 11(1), 1-4.

Hemmati, R., \& Maktabian, M. (2013). A study of the situation of gender inequality among selected middle Eastern countries: Emphasizing the status of Iran, Women's Research Paper, Human Sciences and Cultural Research Institute, 4(2), 115-142.

McGrath, H. C., Henham, M. L., Corbett, A., Durazzi, N., Frearson, M., Janta, B., Kamphuis, B., Katashiro, E., Brankovic, N., Guerin, B., Manville, C., \& Schweppenstedde, D. (2014). Higher education entrance qualifications and exams in Europe: A comparison. Brussels: European Parliament. No 5, 79-98.

Horn, D. (2011). Essays on educational institutions and inequality of opportunity. A Doctoral Dissertation. Submitted to the Central European University in partial fulfillment of the requirements for the Degree of Doctor of Philosophy.

Ichinose, T. (2017). An analysis of transformation of teaching and learning of Japanese schools that significantly addressed education for sustainable development. Journal of Teacher Education for Sustainability, 19(2), 36-50.

Klasen, S. (2002). Low schooling for girls, slower growth for all? Cross country evidence on the effect of gender equality in education on economic development. The World Bank Economic Review, 16(3), 345-373.

Lane, M. (2011). Ancient political philosophy, In the Stanford Encyclopedia of Philosophy. Retrieved from http://plato.stanford.edu/archives/fall2011/entries/ancient-political

Leinonen, T. (2000). Equality of education: a comparative study of educational ideologies of the World Bank and the government of Zambia in 1971-1996. University of Tampere.

Linh, V., Thuy, L., \& Long, G. (2010). Equity and access to tertiary education: The case of Vietnam. Working Papers 10, Development and Policies Research Center (DEPOCEN), Vietnam.

Literature Review on Equity and Access to Tertiary Education in the East Asia Region. Overall World Bank.

Masoudi, E. (2001). Designing an equal access model for applied academic opportunities, Ph.D. Thesis. Tehran, Islamic Azad University, Research and Development Unit.

Matross Helms, R. (2008). University admissions worldwide. International Bank for Reconstruction and Development and the World Bank, Washington.

McDonough, P., Fann, A. (2007). The Study of Inequality In Sociology of Higher Education. Contributions and their Contexts, edited by P. Gumport. Baltimore, MD: The Johns Hopkins University Press.

Mousavi, M., \& Hassani, M. (2011). Measuring the degree of development and exclusion of education areas of West Azerbaijan province, final report of Urmia University research project.

Mukoro, A. S. (2013). The phenomenon of gender inequality in access to and equity in university education in Nigeria. Mediterranean Journal of Social Sciences, 4(7), 129-136. doi: 10.5901/mjss.2013.v4n7p129

Mullen, F. (2010). Barriers to Widening Access to Higher Education. SPICe Briefing.

Necate, B., Duygu Aydemir, Bahar Uyarošlub. (2014). Inequality in educational opportunities of gifted and talented children in Türkiye, Procedia - Social and Behavioral Sciences, 143, 1133-1138. 
Nelson, T. (2012). Social justice and equity issues in the higher education. Retrieved from https://safeguardingstudentlearning.net

Noghani, M., \& Ahanchiyan (2011). The impact of economic, social and cultural capital on the success in the global entrance examination, sociology of education, 1(1), 218-191.

Nowghani, M., Ahanchian, R., \& Rafiee, M. T. (2010). The impact of economic, social and cultural assets on success in nation-wide university entrance exam. The Sociology of Education, 1(1), 191-218.

OECD. (2001). The DAC guidelines, strategies for sustainable development.

Opheim, V. (2004). Equity in education thematic review. CNIFU, country analytical report, Norway, 1-84.

Pignataro, G. (2011). Equality of opportunity: Policy and measurement paradigms, journal of economic surveys, University of Bologna, 26(5), 89-98.

Pipere, A., Veisson, M., \& Salite, I. (2015). Developing research in teacher education for sustainability: UN DESD via the Journal of Teacher Education for Sustainability. Journal of Teacher Education for Sustainability, 17(2), 5-43.

Poorpaki, A. (2014). A study of new approaches in a dynamic and effective education system. Research Institute for Education Studies, quoted from the View of the Ministry of Education, first week, 28-41.

Prodan, A., Maxim, E., Manolescu, I., Arustei, C., \& Guta, A. (2015). Access to higher education: Influences and possible implications. 7th International Conference on Globalization and Higher Education in Economics and Business Administration.

Qian, X., \& Smyth, R. (2008). Measuring regional inequality of education in china: widening cost-inland gap or widening rural-urban gap? Journal of International Development, 20(1), 132-144.

Rawls. J. (1971). A theory of justice Cambridge Harvard University press, 1-98.

Rees,G., Taylor, C., Davies, D., Drinkwater, S., Evans, C., \& Wright, C. (2015). Access to higher education in Wales. Wales Institute of Social and Economic Research, Data and Methods (WISERD).

Sameri, M., Hassani, M., Seyyed Abbaszade, M. M., \& Mosavi, M. N. (2016). Modeling reduction of educational inequalities and equity graduate among high school students in West Azarbaijan Province. Management on the training of organizations, $3(1), 45-72$.

Sameri, M., Hassani, M., Seyyed Abbaszade, M. M., Mosavi, M. N. (2014). Explaining educational inequalities and presenting an educational development model for investigating and attaining the educational justice: Educational areas of West Azarbaijan. Geography and Urban-Regional Planning, 14(1), 122-105.

Samons, P. (2010). School effectiveness and equity: Making connection, education trust. CFBT www.cfbt.com, 1-22.

Schultz, T. W. (1961). Investment in human capital. American Economic Review, 51(1), 1-17.

Shir Karami, J., \& Bakhtiarpour, S. (2014). Evaluation of inequalities in access to educational opportunities: By case study of Dehloran primary schools in the years 2011-2012. Journal of Education and Evaluation, 26, 58-41.

Sobhani Nejad, M., Shah Hoseini, N., Hashemi, M., \& Khodabandeh, A. (2013). Factors affecting the success of Yazd province students to earn the first rank of entry into the universities of the country. Journal of Educational Planning Studies, 2(3), 22-39. 
UNESCO. (2015). The official United Nations site for the MDG indicators. Millennium Development Goals Indicators, 1-25.

Uribe Correa, L. (2012). Access to higher education in Colombia: An assessment of public policy and outcomes. A dissertation submitted to the university at Albany, state university of New York in partial fulfillment of the requirements for the degree of doctor of philosophy.

Vukasocic, M., \& Sarrico, C. S. (2010). Inequality in higher education. Definitions, measurements, inferences, the Serbian Case. In Goastellec, G. (Ed.), Understanding Inequalities in, through and by Higher Education. Sense Publishers: Rotterdam, 116.

Veissona, M., \& Kabaday, A. (2018). Exploring the preschool teachers' views on professionalism, ouality of education and sustainability: International study in Estonia and Turkey. Journal of Teacher Education for Sustainability, 20(2), 5-18.

Yakaboski, T., \& Nolan, K. (2011). The Kenyan school systems' impact on public higher education access: Examination of growth, access, and challenges. Journal of International Education and Leadership, 1(1), 1-13.

Correspondence concerning this paper should be addressed to Mohammad Hassani, Professor of Educational Administration, Faculty of Literature and Humanities, Urmia University 165, Urmia, Iran. Email: m.hassani@urmia.ac.ir 